\title{
OVERDRAFT FACILITY POLICY AND FIRM'S PERFORMANCE: AN EMPIRICAL ANALYSIS IN EASTERN EUROPEAN UNION INDUSTRIAL FIRMS
}

\author{
Leopoldo Laborda Castillo ${ }^{1}$, Daniel Sotelsek Salem ${ }^{2}$ \\ Colegio de Trinitarios, University of Alcalá, Alcalá de Henares, 28801 Madrid, Spain \\ E-mails: ${ }^{1}$ llabordacastillo@gmail.com (corresponding author); ${ }^{2}$ daniel.sotelsek@gmail.com
}

Received 07 July 2011; accepted 06 June 2012

\begin{abstract}
This article evaluates the effect of the overdraft facility (or line of credit) policy by comparing a large sample of overdraft facilitated firms and matched non-overdraft facilitated firms from Eastern Europe at sector level. The sample firms are compared with respect to rates of different performance indicators including: technical efficiency (a Data Envelopment Analysis - DEA - approach is applied to estimate technical efficiency level for individual sectors), production workers trained, expenditures of R\&D, and export activity. In order to avoid the selectivity problem, propensity score matching methodologies are adopted. Results suggest that a certain level of overdraft facility given to a firm would be needed to stimulate investment in $R \& D$, which will eventually result in growth in productivity.
\end{abstract}

Keywords: overdraft facility policy, propensity score matching, technical efficiency, Data Envelopment Analysis (DEA), bootstrapping.

Reference to this paper should be made as follows: Laborda Castillo, L.; Sotelsek Salem, D. 2013. Overdraft facility policy and firm's performance: an empirical analysis in Eastern European Union industrial firms, Journal of Business Economics and Management 14(5): 886-902.

JEL Classifications: C40, H43, H8, L25, L26, L53.

\section{Introduction}

The overdraft facility ${ }^{1}$ policy from private financial institutions provides financial support to increase firms' accessibility to private financing sources. However, according to the IMF (2005) the overdraft facility policy has often been criticized for its negative effects by impairing the development of an innovative private financial sector and for making firm highly dependent on government support policy measures. Even though there have been some qualitative remarks on the effectiveness of the policy, an evaluation of the overdraft facility policy has not been conducted systematically in terms

\footnotetext{
${ }^{1}$ An overdraft facility is defined as a flexible account that allows firms to draw upon in the event their account balance becomes negative.
} 
of methodology and data, especially in Eastern European Union Industrial firms. This study aims to fill the gap in the existing literature.

In this work, we evaluate the effect of the overdraft facility policy in terms of Human Capital (production workers trained), Technological Capital (expenditures of R\&D), competitiveness (sales export level) and the firm's technical efficiency in the Eastern European Union Industrial firms, by comparing overdraft facilitated firms and nonoverdraft facilitated firms. The amount of funds allocated to the overdraft facility policy is huge and the number of targeted firms is large. Therefore, we need to investigate its effectiveness and to provide background information for further evolution of the policy.

This work utilizes an original dataset that covers manufacturing firms in 11 Eastern Europe Countries (Bulgaria, Czech Republic, Estonia, Hungary, Latvia, Lithuania, Moldova, Poland, Romania, Slovak Republic, and Slovenia). Moreover, we analyze the effectiveness of the overdraft facility in 4 industrial sectors (Beverages, Food, Garments, and Metals and machinery).

Methodologically, reliable policy evaluation should solve the 'selectivity' problem. According to Muthen and Jöreskog (1983), selectivity problems can occur whenever one tries to estimate population parameters from a nonrandom sample. The sample may be nonrandom because only firms with certain characteristics are selected into the sample (sample selection), or because firms participate voluntarily in the sample (selfselection). Selective samples can also occur because firms fall out of the sample for various reasons, despite an initial random sample (attrition). According to Jaffe (2002), if we cannot control the selectivity problem, we might over- or under-estimate the true effects of the policy.

In order to deal with the selectivity issue, we adopt propensity score matching estimators, which have recently been applied to firm-level studies (Yasar, Rejesus 2005; Loof, Heshmati 2005; Oh et al. 2009). Propensity score matching was chosen because: (i) it reduces (although does not eliminate) selection biases, (ii) it reduces the limitation from matching on many observable variables for finite data, and (iii) it is best suited to the structure of the available data.

This study is organized as follows. The following section introduces the economic environment of the Eastern European Union Industrial firms and the existing overdraft facility policy schemes. Section 3 briefly explains the methodologies of Data Envelopment Analysis (DEA) Frontiers (with Bootstrap procedure) and propensity score matching. Section 4 describes the data and it presents the key descriptive statistics. The empirical results are discussed in Sect. 5. The final section summarizes and concludes this study.

\section{Background}

\subsection{The Eastern European Union companies}

The EU enlargement to 27 countries in 2004 and 2007 constitutes a historical benchmark in the forming of the European space. In contrast to previous enlargements, the entering of Eastern European countries has peculiar characteristics due to the large 
number of nations entering the EU and due to the heterogeneity in its parameters and levels of development (Hay 2003: 13).

In terms of rent per capita, the set of the countries of Eastern Europe was placed in 2004 in 4,380 Euros (current exchange rates) and 9,100 (PPP) Euros, respectively, which supposed $20 \%$ and $40 \%$ of the per capita income in the Europe of the fifteen. By countries the issue was somewhat different: in the case of Rumania the number in PPP was of $24 \%$ whereas in Hungary the per capita income was almost a $70 \%$ of the EU15.

Another trait to consider is the characteristic of its productive structure: in the countries of the enlargement, more than $20 \%$ of the population was occupied in the agricultural sector whereas in the EU15 that percentile was of $4.8 \%$. Among the countries one can highlight are Romania (40\%), Bulgaria (28\%) and Poland (26\%). As far as foreign trade is concerned, the entailment of the 12 countries with the EU15 (exports and imports) approximately reached $60 \%$ of its trade balance whereas for the EU15 that value remains below 2.5\% (Alcalá 2004).

At the micro level, it is interesting to analyze the behavior of companies from the point of their technical efficiency, as well as of their contribution to the value chain, which will allow shedding light on some conclusions on policy priorities, not only among the countries but among the productive sectors. In this context, a variety of features distinguish the business environment in sectors from those typically observed in the OECD (2001).

We will begin by mentioning the most remarkable and generally acknowledged among them, as identified by Tybout (1992): (a) Market size. Although some economies are quite large, most are not. Hence, with the exception of countries such as Poland or Romania, the size of the domestic market for manufactured products is relatively limited; (b) Access to manufactured inputs. The set of choices of domestically produced intermediate inputs and capital equipment is also often limited; (c) Human capital. Low rates of secondary education (less than 90\%) and an insufficiency of technicians and scientists in countries like Hungary or Lithuania also affect the mix of goods manufactured and the factor proportions used to produce them; (d) Infrastructure. Roads, ports, airports, communication facilities, power, and safe water access also tend to be relatively limited in all countries, although they especially affect countries like Bulgaria or Moldova; (e) Financial markets. Credit markets are also relatively thin in countries like Romania or Moldova; (f) Volatility. Macroeconomic and relative price volatility is typically more extreme in countries like Romania or Moldova than in other economies like the Czech Republic or Lithuania. And finally (h) Governance. Red tape is also relatively high in countries like Poland or Romania, for this reason the protection of contract enforcement can be problematic.

\subsection{The overdraft facility policy}

According to Lerner (2002), firms, especially young and high-tech firms, face great difficulties in accessing the loan market due to asymmetric information which arises from the lack of public information on standardized financial statements and further growth potential. In this context Stiglitz and Weiss (1981) showed that in equilibrium 
a loan market might be characterized by credit rationing. Due to imperfect information and followed adverse selection and moral hazard, market failure occurs in the firms loan market and banks are more likely to demand collateral in loan contracts (Cowling 1998), and it is often difficult for firms to borrow funds, even at higher interest rates.

There exist some recently published studies aimed at analyzing and evaluating overdraft facility policy schemes in various countries. In the case of the UK, Cowling and Mitchell (1997), the overdraft facility policy scheme has successfully addressed a real capital constraint for the majority of firms which applied to the scheme.

In the case of Malaysia, Boocock and Shariff (2005) evaluated the overdraft facility policy scheme in terms of finance additionality, i.e. an increase in accessibility to loans, and economic additionality, i.e. utilizing the funds to benefit their own firms and to generate positive spillovers. These authors concluded that Malaysian overdraft facility policy schemes in general failed to satisfy financial additionality, though it showed some positive outcomes in relation to economic additionality.

Kang (2005) and IMF (2005) shared the views that the nonselective financial support of firms was one of the key sources of the sluggish firms restructuring process after the financial crisis. They argued that a too generous and non-selective guarantee provision worsened the firm market environment in two ways: the first was the effect of crowding out the private financial sector. The second and long-term negative effect was to make firms become more dependent on public support.

In the case of Korea, Lee (2006) criticized that firms with low creditability will gradually receive overdraft facility by excessive supply. It will eventually increase the credit default ratio and hence financial difficulties for government in the end.

Using a data from a cross-section of Bulgarian firms Gatti and Love (2008) estimate the impact of access to credit, as proxied by indicators of whether firms have access to a credit line or overdraft facility, on productivity. These authors find credit to be positively and strongly associated with TFP.

Augier, Dovis and Gasiorek (2012) focuse on the role of the business environment in understanding differences in the performance of Moroccan firms. The evidence on the relationship between credit and productivity is strongly indicative of credit resources misallocation in Morocco.

Kasseeah (2011) studies the link between firm performance and firm characteristics of small and medium-sized enterprises (SMEs) in Mauritius. This author observes that the growth of SMEs in Mauritius depends mainly on access to finance and firm size. Access to finance is captured through access to overdraft facilities, line of credit and self reported measures of access to finance.

Butler and Cornaggia (2011) study the relation between access to finance and productivity. These authors exploit an exogenous shift in demand for a product to expose how producers adapt their productivity in the presence of varying levels of access to finance. These authors find that production increases the most over the sample period in areas with relatively strong access to finance. 
Using a panel of Chinese manufacturing firms over the period 2001-2007, Chen and Guariglia (2011) find that, especially for illiquid firms, productivity is strongly constrained by the availability of internal finance. Furthermore, these authors find higher sensitivities of productivity to cash flow for private exporters, but lower sensitivities for foreign exporters.

Finally, Clarke, Cull and Kisunko (2012) study how country and firm characteristics affected firms' financial constraints and their likelihood of survival during the early phase of the recent global financial crisis in Eastern Europe and Central Asia (ECA). These authors find that financial constraints during the crisis were less severe in countries with well-established foreign banks, and that changes in the severity of financial constraints were more pronounced for large firms than others during the crisis. Controlling for other relevant characteristics, firms were more likely to survive the crisis if they had access to external credit.

\section{Methodology}

Although there is no consensus among researchers regarding the way to establish the process to evaluate the influence of environmental variables on service efficiency levels, in this paper we have attempted to detect the repercussion of certain exogenous factors on the said efficiency levels by using a two-stage process made up of the following steps:

1) Obtaining the Charnes, Cooper and Rhodes (CCR) efficiency index. In order to calculate efficiency, the behavior of each unit observed is optimized, thus determining the efficient production frontier by means of linear segments based on the Decision Making Units (DMUs) that operate with the best practices (Cooper et al. 2001: 3).

2) Using re-sampling methods and bootstrapping techniques. We have opted for the traditional application of determinist mathematical models, and as a complement to them, we have used the re-sampling methods and bootstrapping techniques, in accordance with the contribution by Simar and Wilson (2000).

3) Assessment of overdraft facility policy impact using Propensity Score Matching (PSM). The objective of the matching is to construct treatment and control groups that are as similar as possible, so that the control group would resemble what would have happened to the beneficiaries in the absence of overdraft facility policy (Rosenbaum, Rubin 1983). The PSM estimation strategy requires multiple steps: (i) estimation of the propensity score, in terms of probability to have overdraft facility given observable variables, (ii) the review of overlap and common support conditions (i.e. which firms are matched) and (iii) assessing matching quality (Rosenbaum, Rubin 1983; Frolich 2004; Abadie, Imbens 2006). 


\section{Data and variables}

The statistical source used for this analysis is the World Bank's Enterprise Surveys (ES). The ES collect data from key manufacturing and service sectors in every region of the world. The Surveys use standardized survey instruments and a uniform sampling methodology to minimize measurement error and to yield data that are comparable across the world's economies.

In order to estimate technical efficiency with DEA, there exists considerable disagreement in empirical literature on the definition of outputs (in the context of multipleoutputs firms) of an industrial institution. Nevertheless, according to Coelli et al. (2005), a commonly-used classification of inputs involves five categories: capital (K), labour (L), energy (E), material inputs (M), and purchase services (S). However in our sample, Capital (K) and Purchased Services (S) are not available.

To ensure the validity of the DEA model specification, an isotonicity test (according to Golany and Roll (1989)) was conducted. On the other hand, Smith (2000) argues that, in order to obtain correct and robust estimates of program effects using PSM, one need to use a broad set of observed firm characteristics in the estimation of the propensity score. We evaluated the effect of overdraft facility policy by observing various aspects of a firm's performance. The outcome variables considered are: technical efficiency, R\&D expenditures, export activities and production workers trained. The definition of variables including firm characteristics and outcomes are explained in Table 1.

Table 1. Definition of variables including firm characteristics and outcomes

\begin{tabular}{|c|c|c|}
\hline \multicolumn{2}{|c|}{ Variables } & Definition \\
\hline \multirow{6}{*}{$\begin{array}{l}\text { Production } \\
\text { Function } \\
\text { (output and } \\
\text { inputs) }\end{array}$} & Sales & $\begin{array}{l}\text { Used as the measure of output for the production function } \\
\text { estimation. For all countries, sales figures in local currency } \\
\text { are converted into USD using PPP conversion factor } \\
\text { to the official exchange rate ratio. }\end{array}$ \\
\hline & Capital Stock & $\begin{array}{l}\text { Book value of all fixed assets }{ }^{1} \text {. For all countries, capital } \\
\text { stock figures in local currency are converted into USD using } \\
\text { PPP conversion factor to the official exchange rate ratio. }\end{array}$ \\
\hline & Labor cost & $\begin{array}{l}\text { Total expenditures on personnel }{ }^{2} \text {. For all countries, labor cost } \\
\text { figures in local currency are converted into USD using PPP } \\
\text { conversion factor to the official exchange rate ratio. }\end{array}$ \\
\hline & Materials & $\begin{array}{l}\text { Total costs of intermediate and raw materials used in } \\
\text { production (excluding electricity, fuel, and water). For all } \\
\text { countries, materials figures in local currency are converted } \\
\text { into USD using PPP conversion factor to the official } \\
\text { exchange rate ratio. }\end{array}$ \\
\hline & Energy Cost & Total annual costs of electricity, fuel, and water. \\
\hline & Other Costs & $\begin{array}{l}\text { Total annual costs of communications services, transport } \\
\text { for goods (not including fuel), and rental of land/buildings, } \\
\text { equipment, furniture, etc. }\end{array}$ \\
\hline
\end{tabular}


End of Table 1

\begin{tabular}{|c|c|c|}
\hline \multicolumn{2}{|c|}{ Variables } & Definition \\
\hline \multirow{4}{*}{ Outcomes } & $\begin{array}{l}\text { Technical } \\
\text { efficiency }\end{array}$ & $\begin{array}{l}\text { CCR efficiency index (Bias-Corrected) by Industry (year } \\
\text { 2005). }\end{array}$ \\
\hline & $\begin{array}{l}\text { Dummy } \\
\text { exporter }\end{array}$ & $\begin{array}{l}\text { Dummy variable that takes value } 1 \text { whem firm is exporter } \\
\text { and } 0 \text { whem firm is non-exporter. }\end{array}$ \\
\hline & $\begin{array}{l}\text { Dummy } \\
\text { production } \\
\text { workers trained }\end{array}$ & $\begin{array}{l}\text { Dummy variable that takes value } 1 \text { if the firm has permanent } \\
\text { full-time productions workers who have been trained } \\
\text { (by the firm). }\end{array}$ \\
\hline & $\begin{array}{l}\text { Dummy } \\
\text { Expenditures } \\
\text { of R\&D }\end{array}$ & $\begin{array}{l}\text { Dummy variable that takes value } 1 \text { if the firm carried } \\
\text { out internal } R+D \text { during } 2006 \text { (performed within this } \\
\text { establishment). }\end{array}$ \\
\hline \multirow[t]{4}{*}{$\begin{array}{l}\text { Treatment } \\
\text { and control }\end{array}$} & $\begin{array}{l}\text { Dummy } \\
\text { Overdraft } \\
\text { facility }\end{array}$ & $\begin{array}{l}\text { Dummy variable that take value } 1 \text { if the firm has } \\
\text { an overdraft facility. }\end{array}$ \\
\hline & Age & $\begin{array}{l}\text { Difference between the year that the firm started operations } \\
\text { and current year. }\end{array}$ \\
\hline & $\begin{array}{l}\text { Dummy Large } \\
\text { firm }\end{array}$ & $\begin{array}{l}\text { Dummy variable that takes value } 1 \text { if the firm has }>99 \\
\text { permanent workers. }\end{array}$ \\
\hline & $\begin{array}{l}\text { Dummy } \\
\text { Medium firm }\end{array}$ & $\begin{array}{l}\text { Dummy variable that takes value } 1 \text { if the firm has } 20-99 \\
\text { permanent workers. }\end{array}$ \\
\hline \multirow[t]{2}{*}{ Matching } & $\begin{array}{l}\text { Dummy small } \\
\text { firm }\end{array}$ & $\begin{array}{l}\text { Dummy variable that takes value } 1 \text { if the firm has }<20 \\
\text { permanent workers. }\end{array}$ \\
\hline & $\begin{array}{l}\text { Dummy high/ } \\
\text { upper-middle } \\
\text { income country }\end{array}$ & $\begin{array}{l}\text { Dummy variable that takes value } 1 \text { if the country } \\
\text { has high/ upper-middle income according with } \\
\text { World Bank (2007). }\end{array}$ \\
\hline
\end{tabular}

Dummy

domestic

owners

Dummy variable that takes value 1 if the firm has private domestic owners and 0 if the firma has Foreign owners.

Notes: ${ }^{1}$ Total annual expenditure for purchases of: machinery and equipment (including vehicles), and land and buildings; ${ }^{2}$ Including wages, salaries, bonuses and social payments.

Source: Adapted from based in OECD (2001) Economic Studies No. 33, 2001/II, and from World Bank (2007).

Most of the variables listed above are related to the firm's risks and growth potential. The size (sales and employment) of a firm is often taken to be a good proxy for the firm's risk (Cowling, Westhead 1996). The amount of fixed capital can be related to the availability of collateral, which can act as a sorting device to decide which firms are to receive loans (Bester 1985). R\&D and technical efficiency of firms are related to the future growth potentials as well as current profitability. The country income level (high/ upper-middle), and the existence of domestic owners are also used to control the firm's risk, value, and growth potential in general. 
The production workers trained will represent improvement in skill or the quality of employees. Variables indicating R\&D and exporter status are introduced to observe if overdraft facility is used to enhance future productivity and expanded production facility. The level of technical efficiency might be an ultimate goal of such a government support policy.

\section{Estimation results}

\subsection{Estimation of technical efficiency}

The results of the analysis of efficiency with monetary inputs are shown in Table 2 . These results reveal the sensitivity of the efficiency measures with respect to sampling variation. The bias-corrected efficiency $(\mathrm{BC})$ reveals that differences in measurement efficiency are of a different magnitude than when the original efficiency scores $(\mathrm{N})$ are considered. For all of the manufacturing sectors, the efficiency declines slightly.

Having found that there exists wide variation in technical efficiency among the sample firms it is important and useful to understand the impact of the overdraft facility policy.

\subsection{Propensity score matching estimation}

To better construct the match, Table 3 below shows tests for mean differences between supported and non-supported groups for the impact and other key variables. Identification of the matching technique to create the propensity score requires that the impact variables are independent of the treatment conditional on the propensity score. Few statistically significant differences between participants and non-participants were observed, with the exception of the large and younger firms being more prevalent among those receiving overdraft facilities.

\subsubsection{Estimation of the propensity score}

The propensity score calculated to reflect the probability of a firm receiving overdraft facility, predicts that firms that are younger are more likely to receive benefits. The score, presented in Table 4, is predicted based upon a logit model controlling for factors such as age, age squared, and dummy variables (size firm, country income level, and domestic owners). Each additional year of existence (age) lowers the likelihood of receiving overdraft facilities. Country income level and owners characteristics do not seem to influence the likelihood of receiving overdraft facilities.

\subsubsection{Review of overlap and common support conditions}

The distribution of the propensity score for the treatment and control groups is presented in Figure 1 to assess whether there are any differences in each group's probability to receive overdraft facility. The distribution for the control group firms is more right skewed, i.e. conditioned towards those firms that are more likely to receive treatment. Observations with a propensity score below 0.10 were dropped, as they had a very low likelihood of being treated. The regions of common support show the observations with propensity scores that were matched are those where the treatment and control groups had similar propensity score values. 


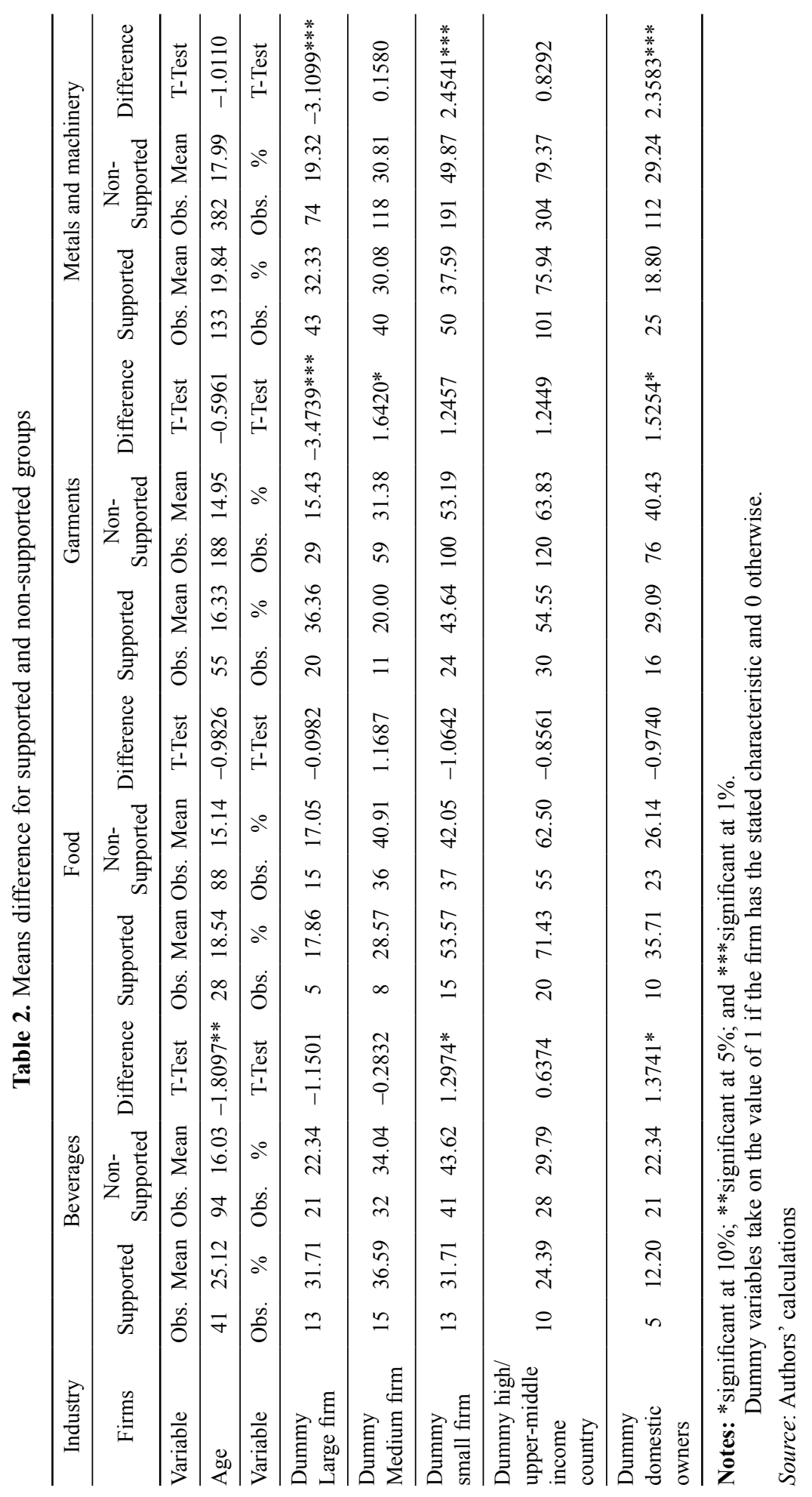


Table 3. Descriptive statistics of the CCR efficiency index (Normal and Bias-Corrected) by industry and country (year 2005)

\begin{tabular}{lcccccccc}
\hline $\begin{array}{l}\text { Country/in- } \\
\text { dustry }\end{array}$ & \multicolumn{2}{c}{ Beverages } & \multicolumn{2}{c}{ Food } & \multicolumn{2}{c}{ Garments } & \multicolumn{2}{c}{$\begin{array}{c}\text { Metals and ma- } \\
\text { chinery }\end{array}$} \\
\hline $\begin{array}{l}\text { CCR effi- } \\
\text { ciency index }\end{array}$ & $\begin{array}{c}\text { Nor- } \\
\text { mal }\end{array}$ & $\begin{array}{c}\text { Bias } \\
\text { Corrected }\end{array}$ & $\begin{array}{c}\text { Nor- } \\
\text { mal }\end{array}$ & $\begin{array}{c}\text { Bias } \\
\text { Corrected }\end{array}$ & $\begin{array}{c}\text { Nor- } \\
\text { mal }\end{array}$ & $\begin{array}{c}\text { Bias } \\
\text { Corrected }\end{array}$ & $\begin{array}{c}\text { Nor- } \\
\text { mal }\end{array}$ & $\begin{array}{c}\text { Bias } \\
\text { Corrected }\end{array}$ \\
\hline Bulgaria & 0.781 & 0.658 & 0.977 & 0.866 & 0.811 & 0.682 & 0.780 & 0.718 \\
\hline $\begin{array}{l}\text { Czech } \\
\text { Republic }\end{array}$ & 0.611 & 0.554 & 0.536 & 0.504 & 0.554 & 0.518 & 0.687 & 0.656 \\
\hline Estonia & 0.547 & 0.492 & 0.503 & 0.430 & 0.609 & 0.566 & 0.777 & 0.722 \\
\hline Hungary & 0.752 & 0.653 & 0.763 & 0.681 & 0.719 & 0.628 & 0.700 & 0.656 \\
\hline Latvia & 0.784 & 0.627 & & & 0.790 & 0.627 & 0.769 & 0.693 \\
\hline Lithuania & 0.751 & 0.645 & & & 0.606 & 0.564 & 0.870 & 0.801 \\
\hline Moldova & 0.665 & 0.598 & 0.525 & 0.485 & 0.560 & 0.521 & 0.664 & 0.637 \\
\hline Poland & 0.624 & 0.571 & 0.678 & 0.617 & 0.663 & 0.620 & 0.726 & 0.685 \\
\hline Romania & 0.708 & 0.636 & 0.759 & 0.682 & 0.706 & 0.629 & 0.733 & 0.682 \\
\hline $\begin{array}{l}\text { Slovak } \\
\text { Republic }\end{array}$ & & & 0.647 & 0.608 & 0.552 & 0.519 & 0.768 & 0.726 \\
\hline Slovenia & 0.702 & 0.616 & 0.673 & 0.621 & 0.927 & 0.781 & 0.912 & 0.814 \\
\hline Mean & 0.693 & 0.605 & 0.673 & 0.611 & 0.682 & 0.605 & 0.762 & 0.708 \\
\hline Soure: DDP & & & & & & & & \\
\hline
\end{tabular}

Source: DDP Quick Query database of WDI \& GDF, World Bank. 


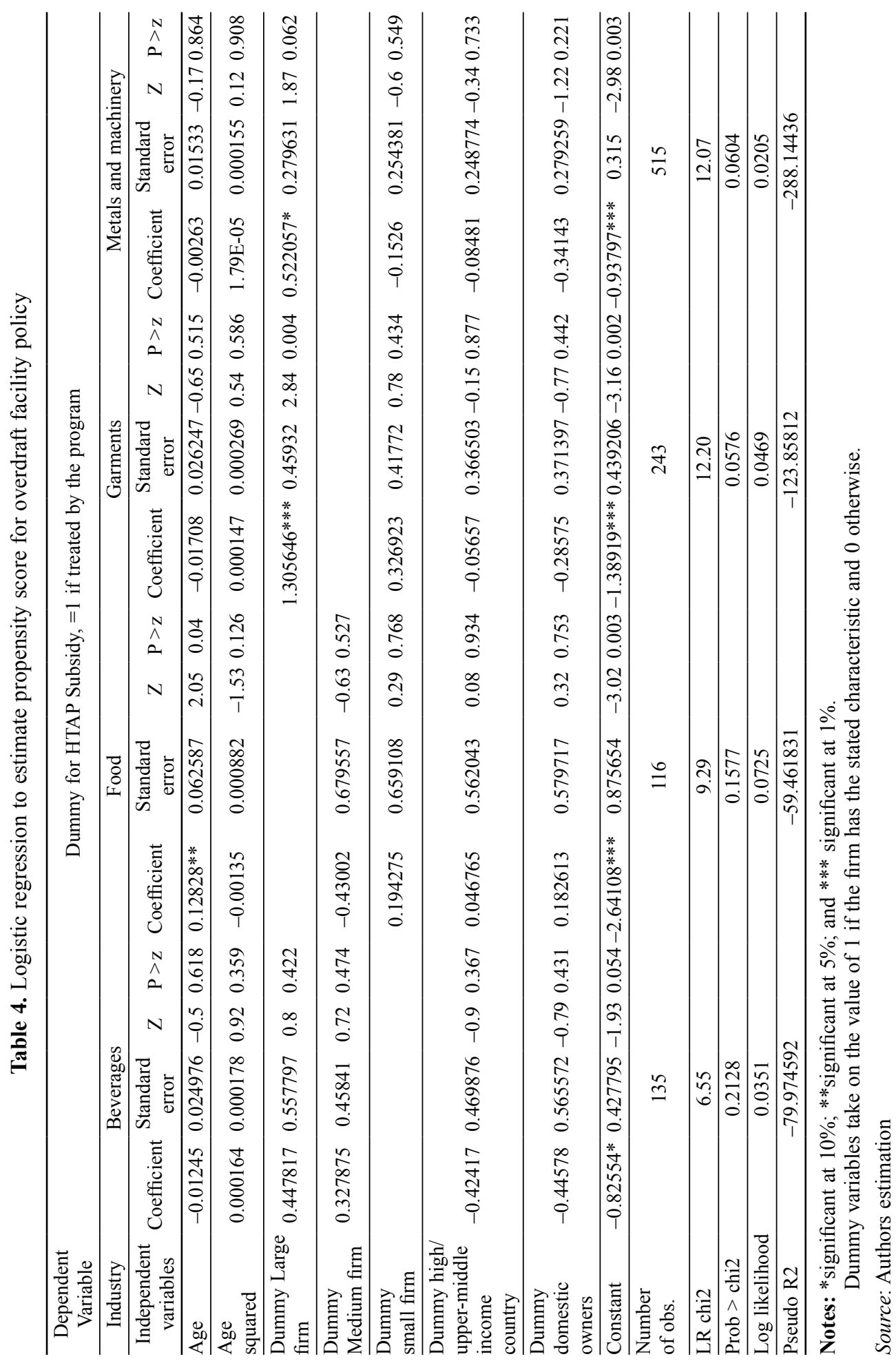



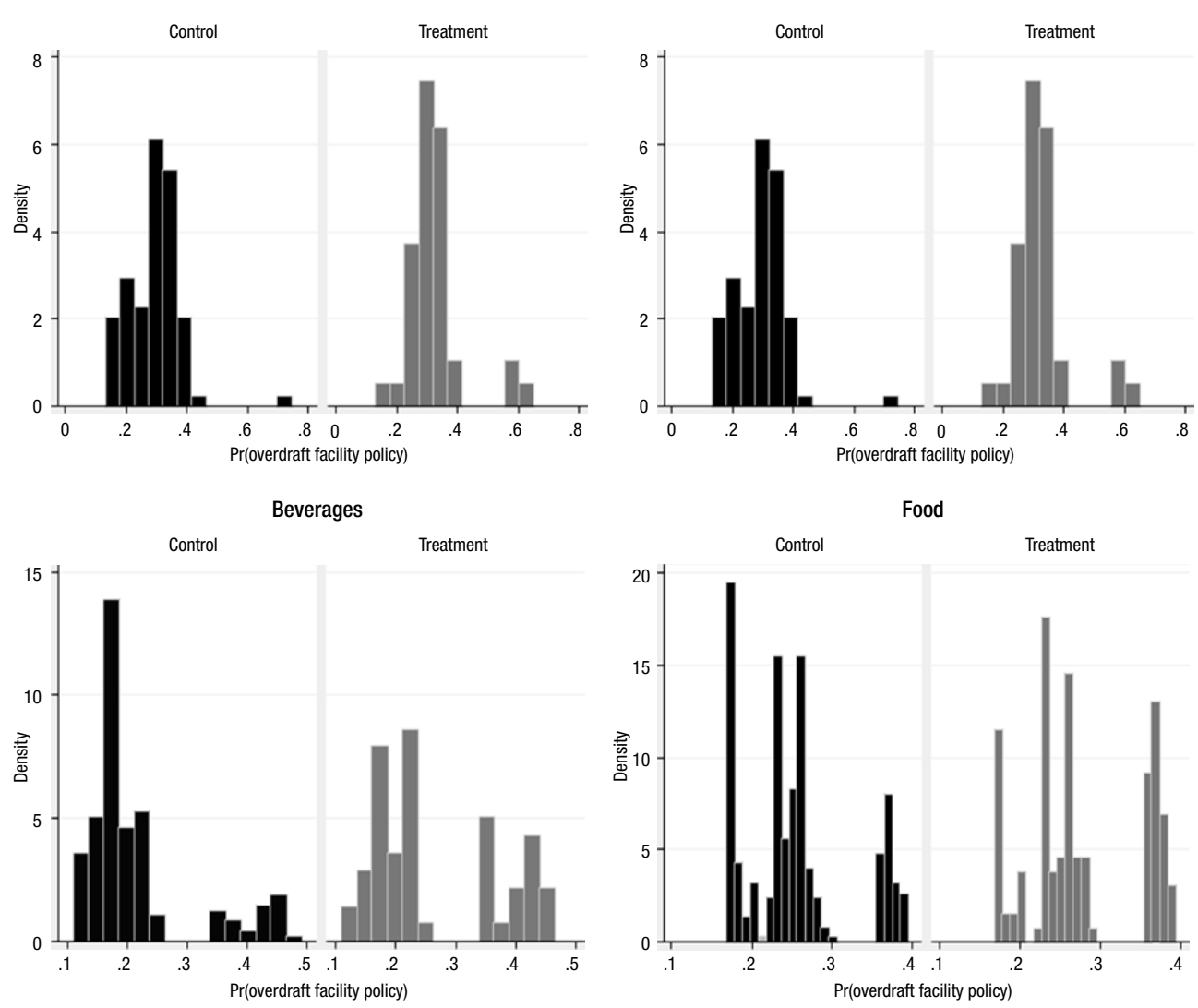

Fig. 1. Distribution of propensity scores by sector

In order to compute Average Treatment Effect on the Treated (ATT) accurately, one should match the supported and unsupported firms precisely on the basis of the propensity score. Table 5 shows the results of the ATT for key outcomes. That is, it shows the difference between the average outcomes for the firms with overdraft facility policy and the average outcomes of those same firms had they not had overdraft facility policy.

The results indicate that the sole statistically significant impact attributable to overdraft facility policy is that these firms have a higher incidence of doing R\&D activities. The sign of the coefficients representing the impact of overdraft facility on expenditures of R\&D activities is positive but only statistically significant in Metals and machinery sector.

\subsubsection{Assessing matching quality}

The quality of the propensity score match is conditional on the validity of the conditional independence assumption. That is, the treatment and control groups should be as similar as possible and have no significant differences in terms of observable and unobservable characteristics. Table 6 shows that following the match observable statistically significant differences between the treatment and control group exist. 


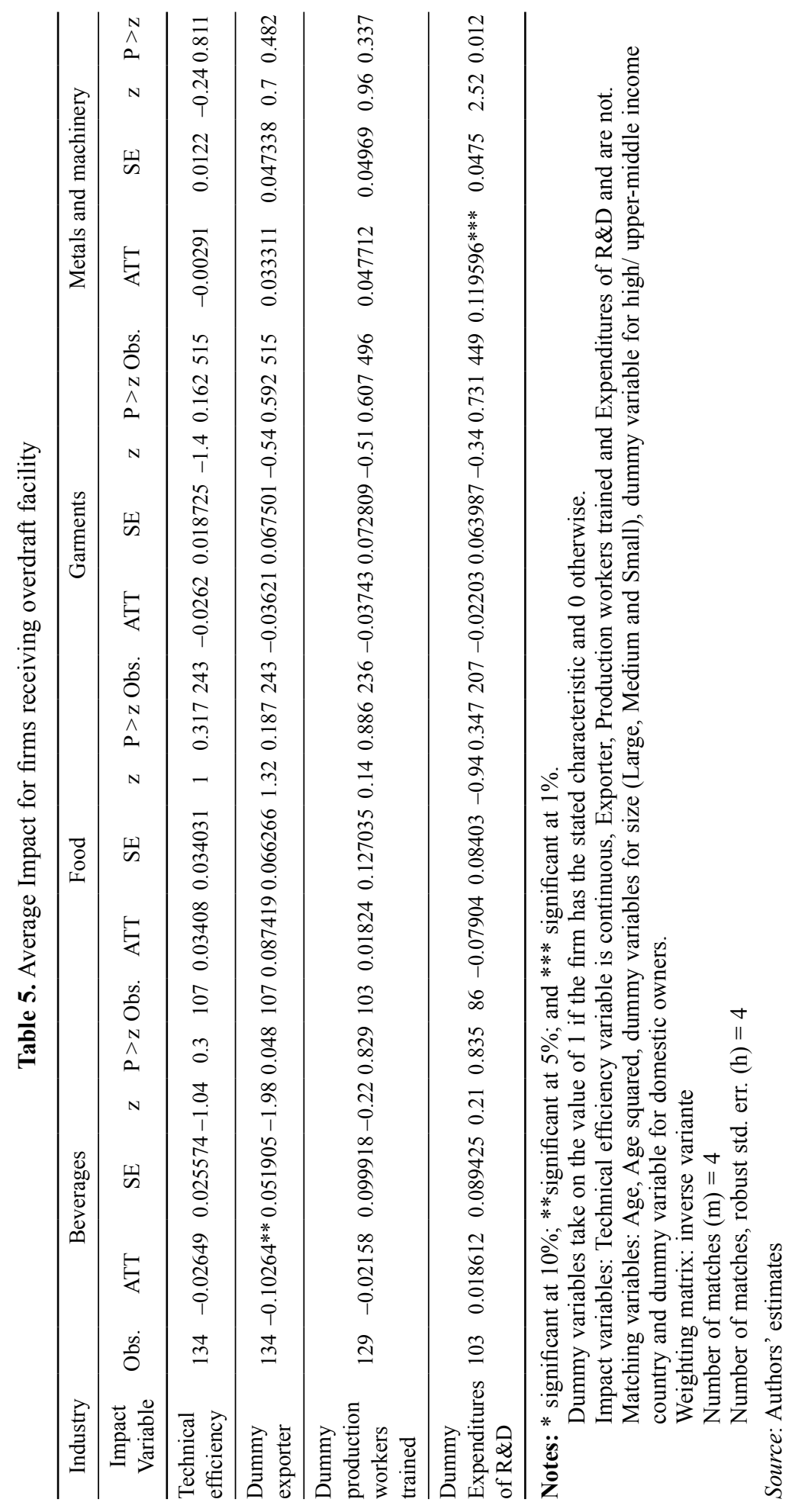




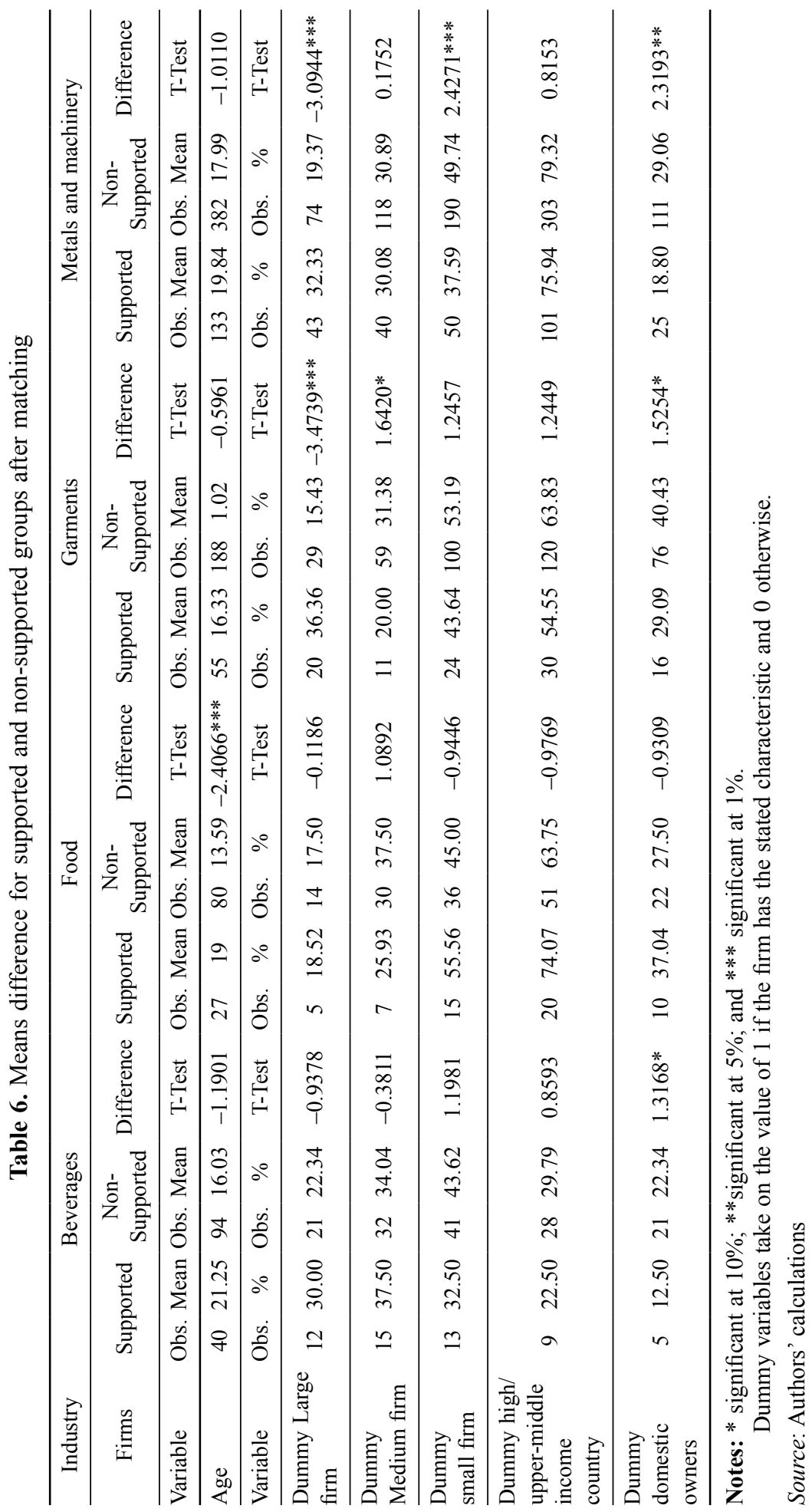


However, to identify a causal relationship, matching requires that the treatment and control groups be similar in unmeasured characteristics. It is uncertain how likely this assumption is because treated firms had the initiative to apply to overdraft facility while the control did not, and there may be other unobserved differences between the treatment and the control group (e.g., the degree of entrepreneurship and quality of management teams).

\section{Summary and discussion of results}

This research evaluates the impact of overdraft facility policy, for recipient firms by controlling the selection bias with the up-to-date propensity score matching technique. The results are based on an investigation of the differences in the performance indicators from 2005, for the firms receiving overdraft facility policy.

In 2005, growth in the eight new European Union (EU) member States from Central and Eastern Europe (EU-8) economies had become more broadly based, driven by robust consumption and investment expenditure and strengthening external demand. On the other hand, most Southern and Eastern European economies had preserved a strong growth momentum in 2005. Finally, macroeconomic policy in most of these countries had remained restrictive.

For all of these factors, 2005 have been chosen to establish performance baseline and establish the impact of overdraft facility policy. In this context, the empirical analysis in Eastern European Union Industrial firms showed that the overdraft facility policy would be needed to stimulate investment in R\&D, which will eventually result in growth in productivity. We could not find sufficient evidence that the overdraft facility has affected positively technical efficiency, production workers trained, and sales export activity.

In terms of policy implications, these findings show that overdraft facility generic programs may not be the best way to increase efficiency or productivity. It would be better to design intervention strategies targeted toward specific sectors and micro-drivers. In the context of the European Union this is much more important since usually there is a tendency to generate general incentive policies that do not take into account the efficiency determinants at the sector level.

However, since this research was based on relatively short period of time not accompanied with significant changes in overdraft facility schemes, the comparative analyses regarding the changes on the parameters were not possible. The designing of these parameters to reach the optimal level could remain as an interesting further research topic.

On the other hand, comparing with today situation, we have been conducting our empirical analysis in a very different economic scenario. In this context, a longitudinal study with new data could provide a greater richness to the results, capturing the effects that persist over time. Extensions of future research could be aimed at addressing the limitations discussed. 


\section{References}

Abadie, A.; Imbens, G. 2006. Large sample properties of matching estimators for average treatment effects, Econometrica 74(1): 235-267. http://dx.doi.org/10.1111/j.1468-0262.2006.00655.x Alcalá, F. 2004. La ampliación de la Eurozona, Información Comercial Española 817: 143-160. Augier, P.; Dovis, M.; Gasiorek, M. 2012. The business environment and Moroccan firm productivity, Economics of Transition 20(2): 369-399. http://dx.doi.org/10.1111/j.1468-0351.2012.00432.x

Bester, H. 1985. The level of investment in credit markets with imperfect information, Journal of Institutional and Theoretical Economics 141: 503-515.

Boocock, G.; Shariff, M. 2005. Measuring the effectiveness of credit guarantee schemes: evidence from Malaysia, International Small Business Journal 23: 427-454.

http://dx.doi.org/10.1177/0266242605054054

Butler, A.; Cornaggia, J. 2011. Does access to external finance improve productivity? Evidence from a natural experiment, Journal of Financial Economics 99(1): 184-203.

http://dx.doi.org/10.1016/j.jfineco.2010.08.009

Chen, M.; Guariglia, A. 2011. Financial constraints and firm productivity in China: do liquidity and export behavior make a difference?, Research paper 2011/09. Research Paper Series China and the World Economy. The University of Nothingan.

Clarke, G.; Cull, G.; Kisunko, G. 2012. External finance and firm survival in the aftermath of the crisis: evidence from Eastern Europe and Central Asia, Journal of Comparative Economics 40(3): 372-392. http://dx.doi.org/10.1016/j.jce.2012.01.003

Coelli, T.; Prasada Rao, D. S.; O’Donnell, C.; Battese, E. 2005. An introduction to efficiency and productivity analysis. $2^{\text {nd }}$ ed. New York: Springer.

Cooper, W.; Park, K.; Yu, G. 2001. IDEA (Imprecise Data Envelopment Analysis) with CMDs (Column Maximum Decision Making Units), Journal of the Operational Research Society 52(2): 176-181. http://dx.doi.org/10.1057/palgrave.jors.2601070

Cowling, M. 1998. Regional determinants of small firm loans under the U.K. loan guarantee scheme, Small Business Economics 11: 155-167. http://dx.doi.org/10.1023/A:1007956403565

Cowling, M.; Mitchell, P. 1997. The evolution of U.K. self-employment: a study of government policy and the role of the macroeconomy, The Manchester School 65: 427-442.

http://dx.doi.org/10.1111/1467-9957.00073

Cowling, M.; Westhead, P. 1996. Bank lending decisions and small firms: does size matter?, International Journal of Entrepreneurial Behaviour \& Research 2(2): 52-68.

http://dx.doi.org/10.1108/13552559610119331

Frolich, M. 2004. Finite-sample properties of propensity score matching and weighting estimators, The Review of Economics and Statistics 86: 77-90. http://dx.doi.org/10.1162/003465304323023697

Gatti, R.; Love, I. 2008. Does access to credit improve productivity? Evidence from Bulgaria, Economics of Transition 16(3): 445-465. http://dx.doi.org/10.1111/j.1468-0351.2008.00328.x

Golany, B.; Roll, Y. 1989. An application procedure for DEA, Omega 17(3): 237-250.

http://dx.doi.org/10.1016/0305-0483(89)90029-7

Hay, J. 2003. Desafios: la Unión Europea ante su ampliación. Madrid: Siddhart Metha Ediciones. IMF 2005. Republic of Korea: 2004 article IV consultation staff report; staff statement; and public information notice on the executive board discussion, IMF Country Report 05/49. Washington, DC: International Monetary Fund.

Jaffe, A. 2002. Building programme evaluation into the design of public research-support programmes, Oxford Review of Economic Policy 18(1): 22-34.

http://dx.doi.org/10.1093/oxrep/18.1.22 
Kang, D. 2005. Corporate distress and restructuring policy of Korean small and medium sized enterprises: role of credit guarantee scheme, in 2005 KDI-KAEA conference, 15 July, 2005, Korea Development Institute, Seoul, Korea.

Kasseeah, H. 2011. Financial constraints, gender and firm performance: evidence from Mauritius, Middle Eastern Finance and Economics 13: 60-70.

Lee, K. 2006. An evaluation of loan guarantee system for S\&M firms in Korea, The Korean Journal of Public Finance 20: 203-229.

Lerner, J. 2002. When bureaucrats meet entrepreneurs: the design of effective "public venture capital" programmes, The Economic Journal 112(477): F73-F84.

http://dx.doi.org/10.1111/1468-0297.00684

Loof, H.; Heshmati, A. 2005. The impact of public funding on private R\&D investment: new evidence from a firm level innovation study, CESIS Electronic Working Paper Series No. 6. Sweden: Centre of Excellence for Science and Innovation Studies.

Muthen, B.; Jöreskog, K. 1983. Selectivity problems in quasi-experimental studies, Evaluation Review 7(2): 139-174. http://dx.doi.org/10.1177/0193841X8300700201

OECD. 2001. Measuring productivity, economic studies, No. 33, 2001/II. Paris.

Oh, I.; Lee, J.; Heshmati, A.; Choi, J. 2009. Evaluation of credit guarantee policy using propensity score matching, Small Business Economy 33: 335-351.

http://dx.doi.org/10.1007/s11187-008-9102-5

Rosenbaum, P.; Rubin, D. 1983. The central role of the propensity score in observational studies for causal effects, Biometrica 70(1): 41-55. http://dx.doi.org/10.1093/biomet/70.1.41

Simar, L.; Wilson, P. 2000. A general methodology for bootstrapping in non-parametric frontier models, Journal of Applied Statistics 27(6): 779-802. http://dx.doi.org/10.1080/02664760050081951

Smith, J. 2000. A critical survey of empirical methods for evaluating employment and training programs, Swiss Journal of Economics and Statistics 136(3): 247-268.

Stiglitz, J.; Weiss, A. 1981. Credit rationing in markets with imperfect information, The American Economic Review 71(3): 393-410.

Tybout, J. 1992. Linking trade and productivity: new research directions, The World Bank Economic Review 6(2): 189-211. http://dx.doi.org/10.1093/wber/6.2.189

World Bank 2007. Enterprise survey: understanding the sampling methodology. New York.

Yasar, M.; Rejesus, R. 2005. Exporting status and firm performance: evidence from a matched sample, Economics Letters 88(3): 397-402. http://dx.doi.org/10.1016/j.econlet.2005.05.001

Leopoldo LABORDA CASTILLO. He works as STC at the World Bank and as Research Associate at the Institute of Latin American Studies in the University of Alcala (Spain). He received his PhD from University of Alcala. His research focuses on productivity and efficiency analysis in public and private sectors.

Daniel SOTELSEK SALEM. He holds a PhD in Economics from the University of Alcalá. Since 1999, he is an Associate Professor at the Department of Economics, University of Alcalá-Spain. His research focuses on financial economics, environmental economics and economic development. 